\title{
State Legal Responses to Historical Institutional Abuse: Shame, Sovereignty and
}

\section{Epistemic Injustice.}

Máiréad Enright, Birmingham Law School

Sinéad Ring, Law Department, Maynooth University

Citation: in Special Issue on Towards Transitional Justice (eds K O'Donnell, M O'Rourke and J. M. Smith) Éire-Ireland: An Interdisciplinary Journal of Irish Studies 55:1-2 (forthcoming Spring-Summer, 2020).

\section{Introduction 1}

The history of the Irish State is littered with shamed bodies. For decades the State collaborated with religious orders in incarcerating children and single women, shamed by their poverty, race, disability, or association with sexual transgression (Fischer Gender, Nation; O’Sullivan and O’Donnell; Smith; Buckley). Shaming practices such as head shaving, using numbers to identify children, or flogging were used to punish and control (Arnold; Coleman 121; Commission to Inquire into Child Abuse [CICA] vol. 1, ch. 8). Women and children in industrial or reformatory schools, psychiatric hospitals, County Homes, and Magdalene Laundries were burdened with a stigmatized identity that meant total exclusion from society (O'Donnell and O'Sullivan 257). As they have begun to speak publicly about their experiences, victim-survivors have forced the State and Irish society to acknowledge this history. Their testimony to experiences of neglect, beatings, forced labor, sexual assault, and imprisonment are an indictment of the sovereign State's claim to protect 
its most vulnerable and to detect and punish crime within its territory. In response, the State offers an architecture of apology, investigation, and redress. Scholars have traced patterns of violation of domestic and international norms at the core of this framework (Gallen and Gleeson; O’Rourke, “The Justice for Magdalenes Campaign”; Ring, “The Victim of Historical Abuse").

These legal responses can usefully be analyzed in terms of the key objectives of transitional justice (truth telling; accountability; redress and reparations, and guarantees of nonrecurrence). However transitional justice and its processes are themselves contingent and capable of oppression. Suppressed and marginalized knowledges may be omitted or excluded in the name of transitional justice (Mamdani; van Marle; Koggel). This article contributes to the literature exploring epistemic injustice in transitional justice processes by scrutinizing the Irish State's legal responses to historical institutional abuse.2 In particular, we develop a theory of State shame that describes and explains the ways the Irish State perpetuates epistemic injustices against people who suffered abuse in State institutions. We unpack the relationship between the State's performance of shame in these legal responses and its need to preserve its sovereignty_-its professed singular competence to determine how painful national events are understood and resolved (Dean). We argue that the State uses discourses of its own shame to legitimate legal responses that prioritize its sovereignty over the demands of true shame. We show how this produces significant epistemic injustices in the present against people who suffered institutional abuse as in the past.

\footnotetext{
2 We do not consider other ways in which law has responded to the demands for justice of historical institutional abuse survivors, such as the jurisprudence emanating from the High Court and Supreme Court on the impact of the passage of time on the fair trial rights of those charged with sexual crimes. Law's role has allowed such prosecutions to take place, albeit at the cost of creating hierarchies of victimhood and of silencing stories of children's resistance to a culture of disbelief (Sinéad Ring, "The Victim of Historical Abuse"). Also see essay by Colin Smith and April Duff in this special issue.
} 
Our argument is in four parts. First, we distinguish between an ideal-type of true shame on the one hand, and the Irish State's discourse of itself as shamed subject (State shame) on the other. We argue that true shame and State shame are very different modes of engaging with past wrongs. While true shame involves a collapse of the sovereign self, State shame preserves the State from any loss of sovereignty. As we show in the second part, a discourse of State shame has been employed to legitimate narrow legalist strategies such as limited inquiries, adversarial interrogation, adherence to fixed evidentiary standards, and a focus on monetary redress to the exclusion of other aspects of reparation. Examining the State's use of law and legalism to respond to the claims for justice of victim-survivors of institutional child abuse and of the Magdalene Laundries, we show how the State produces unitary official histories, monetizes and commodifies harms raised in victim-survivors' testimony, and preserves old hierarchies of power between State, religious orders, and victim-survivors. In the third part, we argue that, in preserving its sovereignty, the State works an epistemic injustice against victim-survivors. Drawing on the work of feminist philosopher Miranda Fricker (2007) we suggest that the legal responses to victim-survivors enact a refusal to listen (testimonial injustice) or to alter the conditions on which victim-survivors can be heard (hermeneutical injustice). In part four we show that State professions of shame, State responses to institutional abuse and epistemic injustice are linked by an investment in sovereignty. In this economy of shame, testimonial injustice is the cost of ensuring that the sovereign State narrative, not victim-survivor testimony, dominates public responses to historical abuse. Hermeneutical injustice is the cost of exalting the State's sovereign ways of framing and knowing historical injustice. State shame, therefore, maintains State sovereignty through unaltered legal technique. We conclude by exploring what engagement with the 
radical potential of shame might mean for imagining new State and community responses that attempt to do epistemic justice to victim-survivors.

\section{Theorizing State Shame}

We use true shame as a heuristic to convey an ideal-type of shame which we can productively compare with the Irish State's discourse of itself as a shamed subject.

Borrowing from Agamben, we understand true shame as an experience of the collapse of the sovereign self (104-105). For Agamben, shame is more than "a feeling that man has." Rather, it is part of the fundamental "hidden structure of all subjectivity and consciousness" (107). Shame comes from our fundamental inability to separate ourselves from how others see us. There is no escape from who we are to others; this intense relationality is what makes shame so devastating (Geunther). We want to flee from our visibility to others but know that we cannot. Agamben describes shaming in vivid terms: "In shame, the subject [...] has no other content than its own desubjectification; it becomes witness to its own disorder, its own oblivion as a subject" (106). True shame, then, is "a kind of existential nakedness" (Janz 464) inseparable from a devastating loss of sovereignty, subjectivity and speech. In shame we witness our own ruin (Mills 104). Without wishing to be definitive or proscriptive, and recognizing the diversity of responses to abuse, we understand these accounts of shame as loss of sovereignty, as resonating with testimony of victim-survivors to the experience of historical institutional abuse in Ireland.

When speaking about historical institutional abuse, State actors often position the Irish State as ashamed of its past: 
The Ryan Commission Report has shone a powerful light into probably the darkest corner of the history of the State. What it has revealed must be a source of the deepest shame to all of us. [...] all of us in Ireland, including the general public, must reflect on what this Report has said about how vulnerable children were treated in Ireland in the past and resolve that from this shame and evil we will make Ireland a model because of the way we treat our children.

An Taoiseach Brian Cowen, T.D. (Cowen, emphasis added)

We cannot, nor will we try to, rewrite history; the conclusions and records of the courts must stand for future generations to see what shame we brought upon ourselves in the name of the Irish republic.

Ruairi Quinn, T.D., Minister for Education (Quinn)

As a society we inherit a deep shame for what was done back then, and we must now endeavor to learn, atone and put things right.

An Taoiseach Leo Varadkar, T.D. (O’Toole)

We argue that, unlike the ideal-type of true shame, State shame as performed in Statements of this kind entails no loss of sovereignty. Rather, the post-authoritarian Irish State's identification with shame has run alongside a new, intensely productive politics of nationbuilding (Fischer "Revealing Ireland's 'Proper Heart'”), reinforcing State sovereignty and inaugurating new techniques of government. This observation is not unique to Ireland. Writing about Australia, for example, Povinelli shows that shame is used to preserve the "good intentions" of a society as it reconfigures its self-understanding in the encounter with its own history (Povinelli 18). By confessing to being "ashamed" of the past, the State 
establishes a temporal logic of exceptionalism rooted in a sense of national change and overcoming (Bewes 38; Enright). Instead of experiencing a collapse of its sovereignty, the State claims ownership of the injustice which must now be overcome. As Ahmed writes of Australia, such performances of State redemption detach shame from victim-survivors' experiences, transforming it from a deeply personal injury to a matter of national authority and identity, which the sovereign State is uniquely competent to understand and address (Ahmed 102). For instance, in apologizing to survivors of the Magdalene Laundries in 2013, An Taoiseach Enda Kenny, T.D., acknowledged their suffering as a "national shame" and announced that the country would "take [their hurt] back" (Kenny). Accordingly, the State seeks to dictate the terms on which the shame of the past is cleansed. It vests itself with the power to revisit others' shaming, to appropriate their experience, and to act to end certain injuries. It owns both the injury and the remedy, and it can control and contain how both are understood.

We now turn to two case studies to develop our theory of State shame in Ireland: legal responses to child abuse in Industrial and Reformatory Schools and legal responses to the abuses perpetrated in the Magdalene Laundries. Industrial and Reformatory schools and Magdalene Laundries were part of a wider network of institutions (which also included psychiatric hospitals, County Homes and Mother and Baby Homes) designed to contain marginalized and stigmatized people. During the middle of the 20 th century over $1 \%$ of the country's population was involuntarily detained in one of these punitive institutions (O’Donnell and O'Sullivan, Figure 1.2).

\section{Institutional Child Abuse}


Industrial Schools were designed to contain children who were powerful reminders of the shame of poverty and unmarried motherhood, 3 and in some cases the shame of having been abused or neglected at home. Reformatory Schools were created to discipline deviant and criminalized boys and girls. In these institutions, shame was a governance technique; in St Joseph's Industrial School, Artane, Dublin, boys were known by numbers rather than their names and were subjected to public inspections of underwear (CICA vol. 1, 234); in St Vincent's Industrial School, Goldenbridge, Dublin, children who had wet their beds were humiliated and forced to parade their wet sheets in front of the other children(CICA vol. II, 275). In St Conleth's Reformatory School, Daingean, Offaly, boys were subjected to arbitrary torture in front of their peers (Bourke 1982). Sexual violence in these institutions thrived on the victims' feelings of shame and self-blame (Kletter et al). When they attempted to report sexual abuse, children were ignored or even blamed by institutional actors and punished severely (CICA vol. IV, 654; Ring, “The Victim of Historical Child Sexual Abuse”).

Institutional abuse of children entered the public discourse in earnest in the 1990s when people began speaking publicly about their experiences. Public concern about child sexual abuse was heightened by the Fr. Brendan Smyth scandal.4 The State was forced to finally respond following the outcry provoked by the television documentary States of Fear (Raftery) which exposed systematic abuse of children in the former industrial and reformatory school system. On 11 May 1999, prior to the airing of the third episode, which

\footnotetext{
3 According to the Commission of Inquiry into the Reformatory and Industrial School System, Report of the Commission of Inquiry into the Reformatory and Industrial School System ('the Kennedy Report')19\% of children in Industrial Schools were "known to be illegitimate." (9)

4 Smyth was a Catholic priest who pleaded guilty to seventy-four charges of indecent and sexual assault, involving the sexual abuse of twenty young people over a period of thirty-six years. He had previously served four years in a Northern Ireland prison for similar offences. The case became notorious when it emerged that the Attorney General delayed processing requests for Smyth's extradition to Northern Ireland where he faced more abuse charges. The Taoiseach Albert Reynolds, T.D., was forced to resign as a result of the political fallout. Smyth's abuse formed the basis of a module of the Inquiry into Historical Institutional Abuse 1922 to 1995 in Northern Ireland (Hart et. al., Report of the Historical Institutional Abuse Inquiry, ch. 10).
} 
highlighted years of inaction and the previous government's suppression of details of an official report into child abuse in the Madonna House residential home in the 1990s (Department of Health), An Taoiseach Bertie Ahern apologized for the State and its citizens' "collective failure to intervene, to detect their pain, to come to their rescue," and promised to learn the lessons of the past. 5 These promises took legal form with the creation of a statutory Commission to Inquire into Child Abuse (CICA) in 2000 and a statutory Residential Institutions Redress Board in 2002, and, in 2013 an agency to support victim-survivors with their ongoing health, education and housing requirements.6 Examination of the operation of each body reveals not a truly shamed State, but one primarily concerned with the management and containment of victim-survivors' justice claims.

The CICA was comprised of two committees: the Confidential Committee and the Investigation Committee. The Confidential Committee provided a forum where victimsurvivors could report their experiences in a confidential setting. The Investigation Committee was tasked with investigating the abuse of children in institutions, including, among other things, the extent to which institutions contributed to the occurrence of abuse. 7 The Investigation Committee held public and private hearings. The Commission's final report (known as "the Ryan Report," after the Chairperson Mr. Justice Sean Ryan) found that sexual abuse was "endemic" in boys' schools (CICA vol. IV, 453), and that there was pervasive neglect, physical and emotional abuse against boys and girls. It also found that the State failed to protect children in Industrial and Reformatory Schools (CICA 2009).

\footnotetext{
5 The implication in the apology that the State had been ignorant of abuse until relatively recently ignored the fact that successive governments had overlooked evidence of institutional abuse, dating back at least as far as the 1970 Kennedy Report. See also James M. Smith, "Remembering Ireland's Architecture of Containment: 'Telling' Stories in The Butcher Boy and States of Fear."

${ }_{6}$ Other State legal responses were the extension of the statute of limitations for civil suits where the claimant had suffered sexual abuse and the creation of a sex offenders register (Sex Offenders Act 2001).

7 For a full list of objectives of both Committees see s12(1) and s15 of the Commission to Inquire into Child Abuse Act 2000.
} 
However, despite its immensely significant findings, its work was far from conclusive in terms of achieving truth recovery or accountability (McAlinden; Pine, Leavy and Keane). The Commission prioritized religious orders' respectability over accountability to victimsurvivors and the public. Pseudonyms were granted to everyone accused of abuse, regardless of whether they had been convicted or not.8 The evidence gathered during the process was not permitted to be used in criminal prosecutions. This cloak of anonymity and effective immunity created a partial history and left many victim-survivors feeling exposed and ignored by the State: "For me, not naming the abusers shows that nothing has changed; the attitude from the State hasn't changed. That apology really meant nothing. As long as they (the religious orders) have money and powerful people behind them, they'll get away with it." (“Alex,” see Pembroke 55).

Second, efforts to provide redress have focused on limiting the exposure of the State and the religious orders to compensation claims. Under the Indemnity Agreement reached on 5 June 2002 between the State and the organization representing the relevant eighteen religious orders (the Conference of Religious in Ireland), 9 the orders promised to contribute $€ 128$ million to the costs of redress. This promise (which has not been honored in full) 10 was given in return for an indemnity against all future legal actions taken by people who as children had been in institutions run by them. However, the indemnity was not based on any apportionment of responsibility for abuse (CICA vol. 1, 14). The indemnity has not in fact been invoked in many cases because the State established a redress scheme in December

${ }_{8}$ See the challenge brought by the Christian Brothers in Michael Murray and David Gibson v the Commission to Inquire into Child Abuse the Minister for Education and Science, Ireland and the Attorney General [2004] IEHC 102. The Christian Brothers dropped their legal actions after the Chairperson announced that the Commission no longer intended to name anyone. See further Brennan, "Facing What Cannot Be Changed." 9 The agreement was not subjected to public scrutiny in the Oireachtas. $10 € 4.21$ million has yet to be paid under this agreement, See McGarry, "Religious Congregations Indemnity Deal." 
2002. Payments were made following a paper application or a hearing. Provision of financial redress was on an ex gratia basis without admission of liability by the religious order or the State. No blame was assigned or accepted. In accordance with normal legal practice, awardees were required to undertake that they would neither sue the State nor the religious order. When details of the scheme were originally announced, it was declared that compensation payments would be broadly equivalent to those awarded in the courts for similar cases. However, the average award was $€ 62,250$, roughly half that made in successful civil cases against religious orders (and in which, under the indemnity agreement, the State was liable) (Comptroller and Auditor General, Special Report 11; Irish Times, "Piling Insult"; Raftery, "Cheating Abuse Victims").

The scheme, which was operational for only three years,11 proved harrowing for many victim-survivors (Coleman, ch. 14). They have described the Board as re-traumatizing (Pembroke) and as discouraging future help-seeking (Moore and Thornton). Some felt so strongly about their treatment that they never spent their awards (Reclaiming Self 26). The hostile environment of the panel hearings distressed many survivors who appeared before them (Coleman 237). Partners or friends of victim-survivors were not allowed to be present when they gave their evidence. In contravention of the ordinary principles of legal procedure, victim-survivors taking part in panel hearings were subjected to cross-examination by legal advisors to the Board on the information provided by the religious orders but without any oral evidence having been given by the orders (Reclaiming Self, Appendix IV (c)). Despite the no-fault basis of the scheme, the Christian Brothers were permitted to issue repeated letters 
denying that any abuse took place in their institutions (McGarry, "Order denied"), 12 thereby adding to victim-survivors' distress. One consultant psychiatrist who gave evidence to the Board on behalf of three patients described it as "contraven[ing] the most basic of human and civil rights" (Corry).

The overall impression of the legal framework for redress is one of secrecy and control. The information provided by the religious orders in response to applications cannot be made public (s28 Residential Institutions Redress Board Act (RIRBA) 2002). Awardees were required to sign a confidentiality agreement promising not to talk about their experience of the scheme or how much compensation they received. They were also sent a letter quoting legislation criminalizing the publication of information relating to a redress application/award that could lead to identification of a person or institution (ss 28(6), (9) RIRBA 2002). The maximum punishment is a fine of $€ 25,000$ and two years' imprisonment (s34 RIRBA 2002).

This theme of censorship is continued in draft legislation that will seal the archives of the Commission to Inquire into Child Abuse and those of the Redress Board and the Review Committee for seventy-five years. Under the Retention of Records Bill 2019 no-one will be allowed access to these bodies' records, including people who gave evidence and their family members, and researchers. Thus the State continues to control victim-survivors' access to their own testimony and is preventing academic and community exploration of these precious histories, which could usefully inform child care policy and practice in the present.13

12 This ended in 2009 when the Ryan Report was published (McGarry, “Order denied”).

13 There is no legislation requiring religious organizations to make their archives accessible to victim-survivors and their families, researchers, the child protection services or the Gardaí (Ireland's police force). 
Third, the statutory agency created to support victim-survivors' health, housing, and educational needs is characterized by its administrative ethos (Caranua). Engagement with clients is primarily through a website, which creates particular challenges for people who cannot read or who do not have access to a computer. Victim-survivors report inordinate delays in processing applications and inaction even following successful appeals. The agency has imposed an upper limit of $€ 15,000$ on each claim, despite clear evidence that some victim-survivors have ongoing medical and related housing needs that will inevitably exceed that amount (Reclaiming Self). Victim-survivors have described Caranua as abusive and disempowering (Irish Times, "Survivors tell of re-abuse"). However, the Government has refused requests to carry out a review of the scheme (Dáil Éireann 2017), and have claimed (incorrectly) that it is independent of the State. Caranua is due to close in late 2019. The State has yet to explain how it will fulfil its continuing obligations to victim-survivors into the future.

Finally, despite An Taoiseach Bertie Ahern's promise in 1999 to learn the lessons of the past, the State continues to extend extraordinary deferential treatment to the religious orders. In the years since the Indemnity Agreement the costs relating to historical institutional child abuse have risen far beyond anything imagined in 2002. Following the publication of the Ryan Report in 2009 the State asked the religious orders to increase their contributions. They offered a further $€ 352.61$ million in cash, property and other resources, a sum that was later revised downwards to $€ 226$ million. As of $2019, € 103.17$ million of this amount has been paid (McGarry, "Religious Congregations"). The total costs of the Commission, redress, and survivor supports are approximately $€ 1.5$ billion (Comptroller and Auditor General Special Report). In short, then, the State continues to indemnify the religious orders from legal liability, while the orders' contributions (under 2002 and the 2009 agreements) come to 
approximately $14.5 \%$ of the total cost. This is far short of the $50: 50$ split originally envisaged by the Department of Finance during the Indemnity Agreement negotiations (Comptroller and Auditor General, Annual Report 83). Nevertheless, deference to the property rights of the religious orders seems to have stymied any suggestion of compulsory acquisition of the orders' assets. Instead, there have only been appeals to the orders" "moral responsibility" (Irish Times, "Religious have 'moral responsibility"').

We now turn to the second case study: the State's legal responses to abuse of women in the Magdalene Laundries.

\section{The Magdalene Laundries}

The Magdalene Laundries were commercial laundries and places of detention run by religious orders with the co-operation of the State. It is believed that from 1922-1996 at least 14,000 women were incarcerated there who had transgressed prevailing Catholic gender norms (Gleeson 295; Titley 132-133). They operated in plain sight, as a normalized part of Ireland's social and economic landscape (Jarrett). However, laundries were also places of shame and seclusion (Perez-Vides; Luddy, 2009). Women were segregated from wider society so that their impurity would not taint others (Killian 18). In the laundries, they were punished as "penitents," who should work for their redemption (Ryan 275; Smith Ireland's Magdalen Laundries; Simpson et. al 11; O’Donnell 82). Shame produced Magdalene women as a distinct legal category (Wilmer 105). Although the courts sometimes substituted detention in a laundry for imprisonment, women were incarcerated without any statutory basis 14 and without being given reasons for their detention, information as to how long they 
would be held, or opportunities to secure their release (Brennan, "Punishing Infanticide" 1213). They were deprived of their names, forbidden to speak, systematically assaulted and neglected with impunity (Gleeson 296; O'Rourke and Smith 107-134). They worked long days unpaid, often for years (O’Donnell 82-83). Women who were pregnant on entry into a laundry (or who became pregnant during their incarceration) were transferred to a Mother and Baby Home where they invariably lost their children to a wider system of coerced adoption (O'Rourke and McGettrick 18). Most women were released after two to three years, but others remained in the laundries until death. Women's deaths in the system were not always recorded and they were often buried in unmarked graves (Gleeson 307; McGettrick). Although the law did not explicitly prescribe the shaming practices endured by these women, the State enforced them, including by the police who returned women to the institutions from which they had attempted to escape (O’Rourke and McGettrick 19; O’Donnell 83). For many victim-survivors of these institutions, the destabilizing effects of the laundries' shaming practices have lasted their whole lives (Fischer, Gender, Nation 836; O'Rourke, "Prolonged Immunity" 134, 137). "I'd still feel a shame and that I'm not the same as other people" (Gleeson, "I never spoke to anybody like this"). Shame has inhibited women's ability to speak about their experiences. "We don't tell everybody that we've been in the laundries. We're ashamed of it, we're embarrassed by it" (Coyne, "Magdalene Laundries").

Initially, the State denied all responsibility for the laundries. A formal institutional response to survivors began in 2013, following a long advocacy campaign by the Justice for Magdalenes group and others (O’Donnell 84-94). The McAleese Report, published in February 2013, found that State agents placed women in the laundries and returned them if they escaped, subsidized the laundries' activities with State contracts and grants, and 
sanctioned non-payment of wages in violation of its own statutes (McAleese; O'Rourke and Smith; O’Rourke and McGettrick 20-22). Two weeks later, Enda Kenny offered a State apology to the women (Kenny). This was initially well received by survivors (O'Rourke, "Prolonged Impunity" 27). In May 2013, Mr. Justice John Quirke published the terms of the "Magdalene Restorative Justice Scheme." The scheme offered ex gratia payments to survivors in an attempt "to reflect the shame of the nation." (Quirke). Payments were not individualized and do not compensate for lost wages or suffering; a pre-set tariff was applied, based only on each woman's duration of stay as verified, in large part, by the religious orders' records. The average payment was $€ 37,386$. Although Quirke recommended that women should receive access to enhanced health services for life, this has not yet been secured.

Three features of the State response are important. First, as with the Ryan Report, the McAleese Report produced a supposedly authoritative "official history" of the laundries that minimized State liability. The McAleese inquiry was offered as an alternative to the "prompt, independent and thorough" investigation twice requested by the UN Committee Against Torture (UNCAT Concluding Observations on First Periodic Report; UNCAT Concluding Observations on Second Periodic Report). This inquiry was not independent of government and had no statutory powers to compel evidence. It heard no public testimony. Despite Justice for Magdalenes' efforts, victim-survivors' voices were marginalized within the report; an archive which they had created to inform the process was ignored.15 The report included women's testimony only as scant, disjointed quotations. As Gallen and Gleeson note,

15 JFM's principal submission, State Involvement in the Magdalene Laundries, ran 175 pages in length and was supported by 796 pages of survivor testimony and an additional 3,200+ pages of archival documentation. None of the testimony appears in the McAleese Report. See http://jfmresearch.com/wp-

content/uploads/2017/03/State_Involvement_in_the_Magdalene_Laundries_public.pdf 
McAleese presented women's accounts of the Magdalene Laundries as mere "stories"

(Gallen and Gleeson 54). These stories were the fragmented remnants of an unsettling and demeaning process, in which women's credibility was not taken for granted. Claire McGettrick remembers the McAleese process:

Initially, the committee didn't even want to speak to women in person, but we fought for that. The women gave their testimony verbally and then we were given very little notice of a second meeting where we were to look at the format of the initial testimony. Instead, the women were brought in one by one for a meeting with the commission where they asked repeated questions. Their overall impression was that they were being checked to ensure that their memories were correct. The women came out of those meetings very quiet and subdued. None of them, none of us, had been expecting for them to be questioned like that. (O'Sullivan)

There was little opportunity for survivors to publicly contest the McAleese account once published. The State discouraged victim-survivors from bringing claims to the courts by contractually requiring them to waive their right of action against the State or State agencies as a condition of participation in the redress scheme. Women were required to take this decision before the State had provided any guarantees on welfare or health provision. This denial of access to the courts was framed as an act of care. For example, the Quirke scheme promised to avoid "mutually antagonistic roles and positions $[\ldots]$ invasive inquiry and interrogation." It spoke of collaborating with women and giving effect to their voice (Quirke 5). In practice, however, the operation of the waiver meant that even those few cases which were not already stymied by the Statute of Limitations could not be brought to court. 
Women's total containment within the redress scheme also has had the effect of denying access to a State forum in which alternative accounts of women's experiences might be shared in public, 16 and reframed as legally cognizable wrongs. O'Rourke notes that the State has repeatedly pointed to the absence of successful litigation by Magdalene women in seeking to deny further liability for the harms they suffered (O'Rourke, "Prolonged Impunity" 28). The State has done little to assist women in disseminating their own histories in other forums, in making sense of their own personal stories,. Records of women's time in the laundries remain in the possession of religious orders, and the State will not make its own related administrative records available for examination by victim-survivors.

Second, as in the case of institutional child abuse, the State's response to Laundry survivors has done little to unsettle perpetrators' privileged social position. McAleese made no recommendations about prosecution or accountability. The waiver which was a condition of participation in the redress scheme also immunized the State from further litigation. Moreover, because the report made no findings as to ill-treatment of women in the laundries (holding that this was "outside its remit") the State is able to maintain that there is no "credible evidence" that women were detained for long periods, tortured, or subjected to criminal abuse (O’Rourke, “The Justice for Magdalenes Campaign” 159). Religious orders were also protected. After the McAleese report, some religious sisters could defend their role in the laundries as provision of a kind of social service (Glynn 45). A similar defense of the religious orders appears in McAleese itself and the report downplays the suggestion that orders profited from women's forced labor (McAleese). The four orders that ran Magdalene Laundries were not compelled to contribute to the redress scheme, despite receiving four

16 The High Court has heard just three reported cases involving Magdalene women since 2013. One of these was appealed to the Court of Appeal. One concerned the exclusion of a woman from the Quirke redress scheme; MKL v. Minister for Justice and Equality [2017] IEHC 389. 
separate invitations to do so. They have ongoing economic relationships with the State, particularly in healthcare and provision of services for sex workers.

Finally, the State reduces duties of reparation to financial redress, privileging limited monetary redress over responding to demands to facilitate survivors in memorializing the dead, or to preserve institutional buildings as museums (Justice for Magdalenes Research). Translating the demand for reparation into a demand for money had two effects. First, it constructed victim-survivors as a burden or drain on the State's finances. Indeed, Quirke emphasized concern for the then-recent economic recession as a check on the scheme (Quirke 25). Relatedly, it subjected individual victim-survivors to State scrutiny and control. Survivors remain, in a sense, objects to be administered. A 2017 Ombudsman's report examining the scheme found that eligibility criteria were narrowly interpreted, and the scheme's administrators preferred to rely on (often incomplete) records held by religious congregations rather than on survivors' affidavits This had a particular effect on women's ability to prove length of stay in a laundry, which meant they received reduced compensation payments (Tyndall 39-42). In addition, women who should have benefited from the scheme were initially excluded; for example, some women who worked in laundries as children registered in an adjoining institution were refused access to the redress scheme because they had not been laundry inmates. Although the High Court found that this was in violation of their rights to natural justice and fair procedures, 17 these women did not eventually receive redress payments until after the publication of the Ombudsman's report, in April 2019. A subsequent process found that 214 applications to the redress scheme required review (Ó Fátharta). Women found the assessment process distressing. Mary Cavner recently spoke about her experience: "It took all of my courage to admit what I had been through and then 17 MKL v. Minister for Justice and Equality [2017] IEHC 389. 
they called me a liar...I have had really low points as they have made me live this again and to be accused of not telling the truth made me feel rejected" (BBC).

Another woman explained the health consequences of engaging with the State redress scheme: "I'm on antidepressants at the moment — of all the things I've been through in my life, I've never been through anything as stressful as this" (Coyne, "Magdalene Compensation"). In an ex gratia scheme, redress is always constructed as a gift of the State, rather than an entitlement of victim-survivors. Elizabeth Coppin speaks of her experience of the Magdalene redress scheme in terms of reinforcement of hierarchies of entitlement: "For me, they're saying again that I don't matter. Again they're ignoring my basic human rights. I bet you all those people in Government are getting their full pension and expenses, yet the Irish women are still being deprived of their entitlements." (quoted in O'Rourke, "Prolonged Impunity" 136)

\section{Shame and State Legal Tactics}

The State expressions of shame following survivor campaigning around institutional child abuse and the harms of the Magdalene Laundries were notionally transformative moments. However, as these examples illustrate, the State is refusing to engage with the full implications of survivors' testimony for its own capacity to judge and remedy past injuries of neglect, physical and sexual abuse, and forced labor.

In the State's legal responses to the Magdalene women and survivors of institutional child abuse we can observe a common pattern. First, the State claims shame at its past (in)action(s). Second it produces a narrow "official history" immunized from victimsurvivors' alternative narratives which, rather than seeking to construct a shared memory of 
past harm, becomes the evidentiary basis for restricting or denying reparations. Third, it preserves the status of State and non-State perpetrators of abuse; limiting their exposure to liability and preserving their reputations. Finally, it reduces reparation to limited monetary redress, delivered via exclusionary schemes that construct victim-survivors primarily as financially-interested claimants. In the next section we argue that this engagement works an epistemic injustice against victim-survivors.

\section{Legal Responses and Epistemic Injustice}

Miranda Fricker advances a concept of "epistemic injustice" that helps us articulate how injustice manifests in Irish State responses to victim-survivors' testimony. In this section we use "testimony" to mean victim-survivors' accounts of the wrongs they suffered, and of the meanings those wrongs should hold for the State and for Irish society. Literature on the "impossibility of bearing witness" doubts whether survivors can ever perfectly recount a traumatic event in terms that represent the atrocity they have experienced (Agamben 39). Questions of justice arise around how the law treats those who offer such testimony. Our claim is that epistemic injustice is a wrong against victim-survivors on top of their existing injuries, an injustice perpetrated in the present by the State in the name of its professed shame at its past.

Fricker describes two forms of epistemic injustice (Fricker 162). The first, testimonial injustice, occurs when the speaker is wrongly deemed unworthy of being taken seriously; in other words, the hearer systematically denies the speaker's position as knower of her own experience and injury (Fricker 16, 20). The State's response to victim-survivors of institutional abuse indicates its refusal to take them seriously; to deem their accounts credible and worthy of belief. This denial of "credibility" is rooted in a prejudiced perception of the 
individual victim-survivor's social status, such as the former resident of an Industrial School, or a former inmate of a Magdalene Laundry. This assignment of an unjustified credibility deficit to the speaker is an epistemic harm. For example, one man who engaged with the Residential Institutions Redress Board said:

[The Board] made me feel like I had done something wrong, the way I was on trial in front of a Judge, and when she questioned my Statement by saying that I would have to be believed because the bastard that abused me was not there to defend himself, I wanted out of there as quick as I could. That was my experience of redress, all it done for me was made me bitter and angry, I was sorry I did not go to court and expose everything that went on in Letterfrack. (Reclaiming Self 26-27, emphasis added).

Describing the Magdalene redress scheme, Diane Croghan recalls a similar sense of exclusion and misrecognition: "I felt like I was a liar; that I was trying to claim for years I wasn't [in a Magdalene laundry] and that's not true. I accepted what they said because I took a stroke and I said no money would repay my good health... I felt I was being punished. I was bullied into accepting it, so I accepted it." (Pollak)

The construction of redress within State schemes can also work a testimonial injustice. Redress schemes have financialized the wrongs done to victim-survivors and suffocated other dimensions of their claims. This leaves victim-survivors feeling that the injuries they suffered are not heard and recognized as wrongs (O'Rourke, "Prolonged Impunity" 136): "I was so disgusted when I received the cheque from the redress board. They did not say they were sorry, they denied they were responsible and I had to accept the money on that basis. I wanted to rip the cheque in half. I never spent a penny of the money, I gave it to my children. 
It was never about the money." (Reclaiming Self 26) This financialization of the harm suffered is even more objectionable when one considers that the State has yet to act on the very first recommendation of the Commission to Inquire into Child Abuse: that a memorial to survivors of institutional abuse be created (CICA vol. IV, 461).

Fricker's second form of epistemic injustice, hermeneutical injustice, involves the speaker being denied an appropriate conceptual framework within which to articulate the wrong done to her. It is an effect of structural inequality. Our collective hermeneutical resources (the shared concepts we use to understand the world) are generally created and maintained by dominantly situated knowers to explain their own experiences, not those of the socially marginalized. According to Fricker, because of systemic disadvantages, marginalized individuals are prevented from understanding and articulating their experiences.18 In the Irish historical institutional abuse context, this account is partly, though not wholly, true. Here we look to Kristie Dotson, who criticizes Fricker's account of hermeneutical injustice for failing to take into account marginalized communities' capacity to develop hermeneutical resources that help them to explain their experience to themselves, and one another, even if these resources are not widely accepted by dominantly situated knowers (Dotson 31, emphasis added). Certainly, there are many examples of victim-survivors of institutional abuse developing their own frameworks for understanding and expressing their experiences, including establishing support groups, and various forms of artistic expression (e.g., Bolger and Quinlan; Costello et al; Doyle; Flynn), for example, and even developing parallel methods for recording their engagements with legal institutions (O'Rourke and McGettrick).

18 Fricker summarizes her two forms of epistemic injustice as follows: "We might say that testimonial injustice is caused by prejudice in the economy of credibility; and that hermeneutical injustice is caused by structural prejudice in the economy of collective hermeneutical resources": Fricker, Epistemic Injustice. Power and the Ethics of Knowing, 1. 
The State's power and ignorance has not prevented victim-survivors from understanding their own oppression and marginalization and from engaging in consciousness raising.

However, if we consider hermeneutical injustice as a denial of conceptual resources with which to articulate the experience to the State, it is clear the Irish State has refused to fully engage with victim-survivors' knowledge and ways of knowing about their/the nation's dark past. The State has failed to reimagine or supplement frameworks of civil and criminal liability, 19 leaving victim-survivors without adequate conceptual means to give public legal expression to their experiences, or to establish new legal discourses of unashamed authority and credibility which might enable them to speak to the State effectively and without fear of sanction. For example, by insulating itself (and religious orders) from meaningful accountability, the State deprives victim-survivors of opportunities to use law to contest the partial accounts of responsibility dispersed through official histories. By limiting access to archives, the State denies them the evidence with which to contest the State's version of events. By subjecting them to ongoing discipline in the determination of their personal histories and in the daily administration of their affairs, the State has denied people opportunities to build relationships with the State that escape older abusive dynamics of power and control, and which might allow for full public articulation of the wrongs done. Thus, the State is acting as an agent of epistemic injustice; a prejudicial exclusion from participation in the spread of knowledge.

In the next section we draw together our discussion of State shame, State legal responses to historical institutional abuse, and epistemic injustice inhering in those responses, to suggest 
that what links these elements in an economy of shame is the State's commitment to protecting its sovereignty.

\section{Epistemic Injustice, Sovereignty and State Shame}

True shame is an extraordinary and devastating ethical situation in which we are inescapably exposed to another's judgement. Shame cannot be controlled or assimilated to the self.20 As we have sought to demonstrate here, the Irish State's response to institutional child abuse and the Magdalene Laundries does not resemble anything approaching this disorder. The causes of the testimonial and hermeneutical injustice we have outlined are rooted in the State's refusal to expose itself to victim-survivors' shaming testimony. By subjecting victimsurvivors to damaging processes, by substituting partial official histories for their testimony, and by censoring access to the archives of the bodies created to learn from the past, the State has co-opted victim-survivors' primary source of power: their unique knowledge about Ireland's recent history of institutional abuse of children and women. Redress schemes have commodified and financialized the wrongs done to survivors; their claims are made about money, suffocating other dimensions of their testimony, such as the need for an apology from representatives of the abuser's community.

This use of law makes sense given that what is at stake is the right to govern. Victimsurvivors' testimony reveals the history of the State as a story of subordination to religious power, which rendered it unable and unwilling to protect its most vulnerable (Enright).

20 Interestingly, for Agamben, shame is not only present in moments of indignity. "Shame is what is produced in the absolute concomitance of subjectification and desubjectification, self-loss and self-possession, servitude and sovereignty" (99). It would be possible for State actors to be shamed, for example, by their own strength and power in the face of witness testimony. 
Victim-survivors' testimony (if it were taken seriously as a source of knowledge about the nation's history) could, we suggest, fully expose the State's complicity in a past failure to protect women and children, and its inability in the present to effectively judge, determine, and redress that failure. Articulated within the politics of representative groups, and offered in multiple different forms, their testimony could cause the State to experience something like true shame; a revelation of inescapable truth that acts as an existential threat to sovereignty. What looks like a response to victim-survivor testimony, then, is actually an avoidance of its threat. The State has many means of controlling and containing victimsurvivor testimony, but the use of law is especially pernicious because it attempts to bring contestation of past wrongs to an end; to bring about "closure" (Christodoulidis 189). It responds to the uncertainty produced by victim-survivor testimony in ways which render the State's liability "finite and calculable" (Schaap 19). It offers recognition to victim-survivors, but only of a kind which subordinates their testimony to the State's preferred epistemic frameworks.

In today's notionally shamed Irish State, testimonial injustice is the cost of ensuring that the sovereign State narrative, not victim-survivor testimony, dominates public responses to historical abuse. Hermeneutical injustice is the cost of privileging the State's sovereign ways of knowing and determining historical injustice. Epistemic injustice, then, is a symptom of the State's prioritization of sovereignty's status quo in moments of supposed transition and change. The State's use of law and legalism perpetrates epistemic injustice against victimsurvivors beyond the harms they have already suffered.

\section{Conclusion}


In this article we have explored the implication of shame in the State's response to the public revelations of institutional abuse of children and women. We have shown that the State has professed to be ashamed of its past, but has responded through law in ways that are antithetical to true shame. Exploring two case studies, institutional child abuse and abuse of women and girls in Magdalene Laundries, we have shown that the State's responses have centered on an investment in sovereignty, and a juridical sense of responsibility for victimsurvivors that is readily exhausted by legalist conceptions of fault, certainty and compensation. This has created legal responses that have perpetrated further epistemic injustices on victim-survivors by refusing to give their claims the credibility they deserve and by failing to provide conceptual resources for the articulation of further testimony. What epistemic justice requires of the ashamed State, on the other hand, is a risky exposure to victim-survivors' testimony and to the possibility that doing so may transform the State and its law.

Such exposure would require a different understanding of State shame than the one the Irish State has used in the past. Despite its misappropriation by the Irish State, shame has radical potential; its "ambivalence bears the possibility of both abjection and solidarity" (Geuthner 35). Precisely because it is de-stabilizing, shame can be transformative; it can awaken a community to new knowledge of its own actions of which it formerly professed ignorance (Zartaloudis 335). Often, this radical potential is not grasped, because shame brings with it the radical risk of de-subjectification — of utter loss of control. Accessing the transformative potential of shame, Bersani and Phillips explain, requires a willingness to dwell with it: "The most difficult thing about shame is to go through with it. This might require an ascetic selfdiscipline.” (Bersani and Phillips 116) 
The ashamed State is only useful to victim-survivors if shame generates an ethical duty on the State to "go through with it"; to bear the risks of engagement with victim-survivor testimony. For Agamben, the fundamental structure of shame generates such a duty. It is, strikingly, a limitless duty to bear witness to the wrongs done to others and to make space for testimony (Agamben 130 [121]); a duty obviously incompatible with the urge to subject that testimony to the controlling forces of legal judgement. From this perspective, the relationship between State shame and epistemic injustice shifts. Epistemic justice can no longer be the casualty of the State's failure to engage with its shame. Epistemic justice is incompatible with mere professions of shame unaccompanied by any radical change in the State's normal legal practices.

That realization, however, generates a problem; what sort of radical change is required? It may be that a law-making State can never go through de-subjectifying and devastating shame of the kind Agamben describes. It may be that we would not wish it to, if that kind of State shame implies a radical passivity that paralyses the State and renders it incapable of acting on victim-survivors' demands for justice (Schaap 27); incapable of anything but permanent withdrawal, "speechless and inert" (Schaap 4). At the same time, the State must find a way to negotiate shame's demands while resisting the urge to repair its unsettling effects. Addressing this problem, Gillian Rose wrote about a "broken middle"; an approach to social and political relations which recognizes that social ruptures cannot be repaired or overcome. We can only negotiate and attempt to comprehend them. The "broken middle" may lie between a paralyzing limitless exposure to testimony of past wrongs, and the insistence that rational formal legal process overcome those wrongs. Following Rose, we would argue that the State cannot choose, ethically, between shame-induced paralysis and a perfect legalism that will dissolve the challenges of history. In particular, an ashamed State would understand that it 
could no longer indulge in unaltered legalism in its engagement with victim-survivors' testimony. Instead, we must negotiate open and responsive paths between limited law and endless shame. Embracing shame as a mode of doing justice to the past in Ireland, then, must mean de-centering and re-configuring established State attitudes to law, allowing new epistemic frames for the voicing and witnessing of traumatic experiences of historical institutional abuse to emerge. This is a process of anxious struggle, far-removed from the comforts of the old sovereignty; the State must risk established practice and "act, without guarantees, for the good of all” (Rose).

Constraints of space mean that we cannot offer a complete program for developing a new legal approach to epistemic justice in the ashamed State's encounter with victim-survivor testimony. Indeed, one of the corollaries of our critique may be a necessary skepticism around the possibilities of prescribing one. However, our argument suggests that Irish legal scholars might attend to three kinds of labor. First, in this article, we have identified how the State produces official histories primarily in an effort to generate an evidentiary basis for containing liability and limiting reparations payments. These official histories have been constructed in ways which seek to replace the testimony which has emerged in spaces more hospitable to victim-survivor testimony. These include activist and scholarly initiatives such as the Waterford Memories Project which preserves oral histories of Magdalene Laundries in an online digital museum (waterfordmemories.com), the Magdalene Oral History Project (http://jfmresearch.com/home/oralhistoryproject/) and the Survivors Stories Project, which recorded the testimony of 16 survivors of institutional child abuse for preservation in the National Folklore Collection. An ashamed State committed to dwelling in and learning from histories of abuse would uncouple its official histories from legal process. It would recognize that efforts to impose closure on its engagement with the past have been premature. It would 
ensure that the historical narratives constructed for State purposes are opened to public challenge and displacement by other bodies of testimony which have been produced in solidarity with and on behalf of victim-survivors.

Second, we have shown how the State preserves the status of State and non-State perpetrators of abuse; limiting their exposure to liability and preserving their reputations. An ashamed State would move away from exclusionary practices of risk-management as its primary approach to victim-survivors. It might also reframe its sense of liability, allowing for scrutiny of the wider history of collective collaboration with coercive institutions (Buckley; Luddy 2007), in contexts of urban and rural fundamentalism (Hannan and Commins).

Finally, we have shown how the State relies on legal frameworks that reduce reparation to limited monetary redress. An ashamed State concerned with epistemic justice must move beyond this habit, and engage seriously with the further claim to support for recovery and dissemination of survivor testimony as an aspect of the demand for reparations. These include formal demands for a national archive of institutional abuse records (O'Rourke “Prolonged Impunity"; O’Rourke and McGettrick, Smith "Commissions of Investigations Act"), a public forum for sharing survivors' stories, and the teaching of histories of institutional abuse in Irish schools (Pine) and across diasporic communities. They might also include support for artistic and community interventions that concentrate primarily on mourning and remembrance. In undertaking each of these three new commitments, an ashamed State would resist the temptations of finality, calculability, and closure, and embrace the risks of open-ended engagement with its past.

\section{Works Cited}


Agamben, Giorgio. Remnants of Auschwitz: The Witness and the Archive. Boston: Zone Books, 1999.

Ahmed, Sara. The Cultural Politics of Emotion. London: Routledge, 2004.

Almog, Shulamit. "Healing Stories in Law and Literature." Trauma and Memory, Reading Healing and Making Law. Eds. Austin Sarat, Michael Alberstein and Nadav Davidovitch. Palo Alto, CA: Stanford University Press, 2007. 289-304.

Arnold, Bruce. The Irish Gulag: How the State Betrayed its Innocent Children. Dublin: Gill \& Macmillan, 2009.

BBC. "Magdalene Laundries Victim Mary Cavner to Get Compensation." BBC.com, 21 Aug. 2019. https://www.bbc.co.uk/news/uk-england-hampshire-49393418.

Bersani, Leo and Adam Phillips. Intimacies. Chicago: University of Chicago Press, 2008.

Bewes, Timothy. The Event of Postcolonial Shame. Princeton: Princeton University Press, 2011.

Bolger, Patrick and Maria Quinlan. "I Am One in Four." Exhibition at CHQ Building, 17 May and accompanying Report. Dublin: One in Four, 2019.

Brennan, Carole. "Facing What Cannot Be Changed. The Irish Experience of Confronting Institutional Child Abuse." Journal of Social Welfare and Family Law 29 (2007): 245-263.

Brennan, Karen. "Punishing Infanticide in the Irish Free State." Irish Journal of Legal Studies 3.1 (2013): 1-35.

Bourke, Seán. “Daingean Days.” Limerick Socialist, 1982, re-published in The Limerick Post 6 June 2009.

Buckley, Sarah-Anne. "Child Neglect, Poverty and Class: The NSPCC in Ireland 1889-1939A Case Study.” Saothar - Journal of The Irish Labour History Society. 33 (2008): 5770 .

Buckley, Sarah-Anne. The Cruelty Man: Child Welfare, the NSPCC and the State in Ireland, 1889-1956. Manchester: Manchester University Press, 2013.

Caranua. Applying for Services Booklet. Dublin: Caranua, 2016.

Christodoulidis, Emilios. "Truth and Reconciliation' as Risks." Social and Legal Studies 9.2 (2000): 179-204.

Coleman, Karen. Haunting Cries, Stories of Child Abuse from Industrial Schools. Dublin: Gill and MacMillan, 2010. 
Commission of Inquiry into the Reformatory and Industrial School System, Report of the Commission of Inquiry into the Reformatory and Industrial School System.

Commission to Inquire into Child Abuse (CICA). Report of the Commission to Inquire into Child Abuse, Volumes I-V. Dublin: Government Publications, 2009.

Comptroller and Auditor General, Annual Report 2002. Dublin: Government of Ireland, 2003.

Comptroller and Auditor General. Special Report on Costs of Child Abuse Inquiry and Redress. Dublin: Government of Ireland. 2017.

Corry, Michael. "Residential Institutions Redress Board.” The Irish Times, 19 May 2005.

Costello, Nancy, Kathleen Legg, Diane Croughan, Marie Slattery, and Marina Gambold. Whispering Hope: The Heart-Breaking True Story of the Magdalene Women. London: Orion, 2015.

Cowen, Brian. "Dáil Debate on the Report of the Commission of Inquiry into Child Abuse." 11 June 2009.

Coyne, Ellen. "Magdalene Laundries Survivors Lose Hope of Compensation". Times. 23 Oct. 2018.

Coyne, Ellen. "Magdalene Compensation Rule is Fair, Says Taoiseach." The Sunday Times, 24 Oct. 2018.

Dáil Éireann. "Residential Institutions Statutory Fund: Motion (Resumed) [Private Members]." 24 May 2017.

Dean, Mitchell. The Signature of Power: Sovereignty, Governmentality and Biopolitics. London: Sage, 2013.

Department of Health and Children. Report on the Inquiry into the Operation of Madonna House. Dublin: Stationery Office, 1996.

Dotson, Kristie. "A Cautionary Tale: On Limiting Epistemic Oppression.” Frontiers - A Journal of Women's Studies 23.1 (2012): 24-47.

Doyle, Paddy. The God Squad. London: Corgi Books, 1988.

Enright, Máiréad. “No. I Won't Go Back': National Time, Trauma and Legacies of Symphysiotomy in Ireland." Law and Time. Eds. Sian Beynon-Jones and Emily Grabham. London: Routledge, 2018.

Enright, Máiréad and Sinéad Ring. Philosophical Perspectives on Contemporary Ireland. Eds. Clara Fischer and Áine Mahon. London: Routledge, 2019.

Flynn, Gerard Mannix. Nothing to Say. 1983. 2nd ed. Dublin: Lilliput Press, 2003. 
Fischer, Clara. "Gender, Nation, and the Politics of Shame: Magdalen Laundries and the Institutionalization of Feminine Transgression in Modern Ireland." Signs 41.4 (2016): 821-843.

Fischer, Clara. "Revealing Ireland's 'Proper' Heart: Apology, Shame, Nation.” Hypatia: A Journal of Feminist Philosophy 32.4 (2017): 751-767.

Fischer, Clara and Mahon, Áine. Philosophical Perspectives on Contemporary Ireland. London: Routledge, 2019.

Fricker, Miranda. Epistemic Injustice. Power, and the Ethics of Knowing. Oxford: Oxford University Press, 2007.

Gallen, James and Kate Gleeson. "Unpaid Wages: the Experiences of Irish Magdalene Laundries and Indigenous Australians." International Journal of Law in Context 14.1 (2018): 43-60

Geunther, "Resisting Agamben: The Biopolitics of Shame and Humiliation" 38.1 Philosophy \& Social Criticism (2011): 58-79

Gleeson, Colin. "I never spoke to anybody like this. Our voices are heard today." The Irish Times. 5 June 2018.

Gleeson, Kate. “A Woman's Work Is Never Done.” Feminist Legal Studies 25 (2017): 291312.

Glynn, Evelyn. "Magdalene Matters.” Engendering Ireland. Eds. Rebecca Ann Barr, SarahAnne Buckley, and Laura Kelly. Cambridge: Cambridge University Press, 2015. 3252.

Hannan, Damian and Commins, Patrick. 'The Significance of Small-scale Landholders in Ireland's Socio- Economic Transition.' In: Goldthorpe, J. H. and Whelan, C. T. (eds) The Development of Industrial Society in Ireland. Oxford: The British Academy, 1992. 79-104.

Hart A, G. Doherty and D. Lane. Report of the Historical Institutional Abuse Inquiry. Belfast, Northern Ireland: Historical Institutional Abuse Inquiry, 2017.

Irish Times. "Piling Insult Upon Injury." The Irish Times 3 March 2005.

Irish Times. "Survivors Tell of Re-abuse by State Redress Group Caranua." The Irish Times 20 March 2017.

Irish Times. "Religious Have 'Moral Responsibility' for Half Cost of Redress Scheme.” Irish Times. 9 May 2017.

Janz, BB, "Shame and Silence" South African Journal of Philosophy 30.4 (2011): 462-471 
Jarrett, Kylie. "Laundering Women's History: a Feminist Critique of the Social Factory," First Monday 23.3 (2018):

Justice for Magdalenes Research. State Involvement in the Magdalene Laundries. 2013. http://jfmresearch.com/wpcontent/uploads/2017/03/State_Involvement_in_the_Magdalene_Laundries_public.pd $\mathrm{f}$

Justice for Magdalenes Research. Preserving Magdalene History. 2018. http://jfmresearch.com/home/preserving-magdalene-history/sean-mcdermott-street/

Kenny, Enda. “Magdalene Laundries: Statements,” Dáil Debates, 19 Feb. 2013. https://www.oireachtas.ie/en/debates/debate/dail/2013-02-19/29/

Killian, S. "For Lack of Accountability: the Logic of the Price in Ireland's Magdalene Laundries.” Accounting, Organisations and Society 43.17 (2015): 17-32.

Kletter H, C. Weems and V. Carrion. "Guilt and Posttraumatic Stress Symptoms in Child Victims of Interpersonal Violence." Clinical Child Psychology and Psychiatry 14.1 (2009): 71-83.

Koggel, Christine M. "Epistemic Injustice in a Settler Nation: Canada's History of Erasing, Silencing, Marginalizing.” Journal of Global Ethics. 18.2 (2018): 240-251.

Luddy, Maria. "Moral Rescue and Unmarried Mothers in Ireland in the 1920s" Women's Studies 30 (2001): 797-817.

Luddy, Maria. "Sex and the Single Girl in 1920s and 1930s Ireland." The Irish Review 35 (2007): 79-91.

Mamdani, Mahmood. "A Diminished Truth.” After the TRC. Reflections on Truth and Reconciliation in South Africa. Eds. Wilmot James and Linda Van de Vijver. Ohio: Ohio University Press, 2000. 58-61.

McAleese, Martin. Report of the Inter-Departmental Committee to establish the facts of State involvement with the Magdalen Laundries. Dublin: Department of Justice, 2013.

McAlinden, Anne Marie. "An Inconvenient Truth: Barriers to Truth Recovery in the Aftermath of Institutional Child Abuse in Ireland.” Legal Studies 3 (2013): 189-214.

McGarry, Patsy. "Order Denied Abuse Five Days Before Report.” The Irish Times. 3 June 2009.

McGarry, Patsy. "Religious Congregations Indemnity Deal Was 'a blank cheque', Says Michael McDowell.” Irish Times. 5 April 2019.

McGettrick, Claire. "Death, Institutionalization and Duration of Stay" (2015) http://jfmresearch.com/wp-content/uploads/2017/03/JFMR_Critique_190215.pdf 
Mills, Catherine. The Philosophy of Agamben. London: Routledge, 2014.

Moore, Jenna. M., Christine D. Thornton, and Mary Hughes. "On the Road to Resilience: the Help-Seeking Experiences of Irish Emigrant Survivors of Institutional Abuse." Child Abuse Review 26 (2015): 375-387.

Ó Fátharta, Conall. "32 Magdalene Survivors Get Increased Redress Payment." The Irish Examiner 7 Sept. 2019.

O’Donnell, Katherine. "Academics Becoming Activists: Reflections on Some Ethical Issues of the Justice for Magdalenes Campaign." Irishness on the Margins: Minority and Dissident Identities. Ed. Pilar Villar-Argáiz. London: Palgrave Macmillan, 2018. 77100.

O'Rourke, Maeve. "The Justice for Magdalenes Campaign.” International Human Rights: Perspectives from Ireland. Ed. Suzanne Egan. London: Bloomsbury Professional, 2015. 153-165.

O'Rourke, Maeve. Justice for Magdalenes Research NGO Submission to the UN Committee Against Torture. Justice for Magdalenes, 2017. http://jfmresearch.com/wpcontent/uploads/2017/07/JFMR-report-to-CAT-for-the-session-2017-Main-Report.pdf

O'Rourke, Maeve. "Prolonged Impunity as a Continuing Situation of Torture or IllTreatment? Applying a Dignity Lens to So-called 'Historical' Cases." Netherlands International Law Review 66.1 (2019): 101-141.

O'Rourke, Maeve, Claire McGettrick, et. al. Clann: Ireland's Unmarried Mothers and their Children: Gathering the Data. 2018. www.clannproject.org.

O'Rourke, Maeve and James M.Smith. "Ireland's Magdalene Laundries: Confronting a History Not Yet in the Past." A Country of Progress? Irish Women Reflect. Eds. Alan Hayes and Máire Meaghar. Dublin: Arlen House, 2016. 107-34

O’Sullivan, Claire. “Interviews Lack Transparency Say Victims' Groups.” Irish Examiner 7 Feb. 2013.

O'Sullivan, Eoin and Ian O'Donnell. Eds. Coercive Confinement in Ireland: Patients, Prisoners and Penitents. Manchester: Manchester University Press, 2012.

O’Toole, Fintan, "Enough Shame About the Past: What We Need is Guilt." Irish Times 23 April 2019.

Pembroke, Sinead. "Historical Institutional Child Abuse in Ireland: Survivor Perspectives on Taking Part in the Commission to Inquire into Child Abuse (CICA) and the Redress Scheme." Contemporary Justice Review 22.1 (2019): 43-59.

Pérez Vides, A. "Disciplined Bodies: the Magdalene Spectacle in Contemporary Irish Cultural Texts." Revista Canaria de Estudios Ingleses. 73 (2016): 15-30. 
Pine, Emilie, Susan Leavy and Mark Keane. "Re-Reading the Ryan Report. Witnessing Via Close and Distant Reading." Eire-Ireland: A Journal of Irish Studies 52.1-2 (2017): 198-215.

Pollak, Sorcha. "Magdalene Survivor: 'They're ignoring my basic human rights' Irish Times 19 Jan. 2015.

Povinelli, Elizabeth. The Cunning of Recognition. Durham: Duke University Press, 2002.

Quinn, Ruairí. "Dail Debate on Institutional Child Abuse Bill 2009: Second Stage," 7 July 2009. https://www.oireachtas.ie/en/debates/debate/dail/2009-07-07/29/\#spk_228

Quirke, John. The Magdalene Commission Report. Dublin: Department of Justice and Equality, 2013.

Raftery, Mary. States of Fear (documentary television series). Dublin, Ireland: Radió Teilifís Éireann (RTÉ), 1999.

Raftery, Mary. “Cheating Abuse Victims.” Irish Times 26 April 2007.

Reclaiming Self. Ryan Report Follow-Up. Submission to the United Nations Committee against Torture Session 61. 2017.

https://tbinternet.ohchr.org/_layouts/15/treatybodyexternal/Download.aspx?symbolno $=\mathrm{INT} \% 2 \mathrm{fCAT} \% 2 \mathrm{fCSS} \% 2 \mathrm{fIRL} \% 2 \mathrm{f} 27959 \&$ Lang=en

Residential Institutions Redress Board. Annual Report 2012. Dublin: Stationery Office, 2013.

Ring, Sinéad. "Trauma and the Construction of Suffering in Irish Historical Child Sexual Abuse Prosecutions.” International Journal for Crime, Justice and Social Democracy. 6.3 (2017): 88-103.

Ring, Sinéad. "The Victim of Historical Abuse in the Irish Courts 1995-2006." Social and Legal Studies 26.5 (2017): 562-580.

Ring, Sinéad. “On Delay and Duration. Law's Temporal Orders in Historical Child Sexual Abuse Cases." Law and Time. Eds. Emily Grabham and Sian Beynon-Jones. London: Routledge, 2018. 93-107.

Ring, Sinéad. “'Our Most Precious Possession of All.' The Survivor of Historical Child Sexual Abuse as the Ideal Victim?" Revisiting the Ideal Victim Concept.

Developments in Critical Victimology. Ed. Marian Duggan. Bristol: Bristol University Press, 2018. 141-158.

Rose, Gillian. Mourning Becomes the Law: Philosophy and Representation. Cambridge: Cambridge University Press, 1996.

RTÉ News. "Taoiseach Issues Apology to Victims of Child Abuse.” 1999. https://www.rte.ie/news/1999/0511/1662-abuse/. 
Ryan, Louise. Gender, Identity and the Irish Press 1922-1937. London: Edwin Mellen, 2002.

Schaap, Andrew, "Political Reconciliation Through a Struggle for Recognition?" Social and Legal Studies. 13.4 (2004): 523-540.

Simpson, A.V., S.R. Clegg, et. al. "Doing Compassion or Doing Discipline? Power Relations and the Magdalene Laundries.” Journal of Political Power 7.2 (2014): 253-274.

James M. Smith, "Remembering Ireland's Architecture of Containment: 'Telling' Stories in The Butcher Boy and States of Fear." Éire-Ireland: An Interdisciplinary Journal of Irish Studies 36, 3\&4 (2001): 111-130.

Smith, James M. "The Politics of Sexual Knowledge: The Origins of Ireland's Containment Culture and the Carrigan Report (1931)." Journal of the History of Sexuality 13.2 2004: 208-33

Smith, James M. Ireland's Magdalen Laundries and the Nation's Architecture of Containment. Manchester: Manchester University Press, 2008.

Smith, James M. "Commissions of Investigations Act Inhibits Truth-Telling About the Past and Present." The Irish Times 30 Oct. 2018.

Titley, Brian. "Magdalene Asylums and Moral Regulation in Ireland." Schools as Dangerous Places: A Historical Perspective. Eds. A Potts and T O'Donoghue. Youngstown, NY: Cambria Press, 2007. 119-144.

Tyndall, Peter. Opportunity Lost: An Investigation by the Ombudsman Into the Administration of the Magdalene Restorative Justice Scheme. Dublin: Office of the Ombudsman, 2017.

UNCAT, Concluding Observations on the First Periodic Report of Ireland. 2011. https://tbinternet.ohchr.org/_layouts/treatybodyexternal/Download.aspx?symbolno $=\mathrm{C}$ $\mathrm{AT} \% 2 \mathrm{fC} \% 2 \mathrm{fIRL} \% 2 \mathrm{fCO} \% 2 \mathrm{f} 1 \& \mathrm{Lang}=\mathrm{en}$.

UNCAT. Concluding Observations on the Second Periodic Report of Ireland, 2017. https://tbinternet.ohchr.org/Treaties/CAT/Shared\%20Documents/IRL/INT_CAT_CO C_IRL_28491_E.pdf.

van Marle, Karin. "Holding Out For Other Ways of Knowing and Being." feministst@law Vol 7.2 (2017). https://journals.kent.ac.uk/index.php/feministsatlaw/article/view/415/1060.

Wilmer, SE. Performing Statelessness in Europe. London: Palgrave Macmillan, 2018.

Zartaloudis, Thanos, Agamben and Law. London: Routledge, 2015. 
